\title{
Meaningful Making in the Contemporary Creative Economy
}

Poorer perhaps financially, but richer emotionally. (Female, ceramics, established maker, November 2016)

And I wanted to make. I think I've always said to myself, I was, if [I could] make enough money from [my] art to live I'll be content. That's just my benchmark. I don't need to be world famous or anything, I just need to make a living doing the things that I love doing.(Clare Poppi, jewellery, established maker, September 2016)

This chapter introduces the people and their stories that inform this book, including the reasons behind their choice to pursue craft or design, despite the frequently precarious incomes to be made. One of the strongest findings to emerge in this study is the centrality of early exposures to making to later comfort with and motivation to give craft and design 'a go'. How the makers connect their current identities to formative earlier familial and educational experiences is explored. These findings are then situated analytically within critical scholarship on the values of crafts-based practice today as they sit alongside the rise of neoliberal individualised work practices, including the normalisation of self-employment and microenterprise, with all the associated personal financial risk-taking this entails.

S. Luckman, J. Andrew, Craftspeople and Designer Makers in the

Contemporary Creative Economy, Creative Working Lives, https://doi.org/10.1007/978-3-030-44979-7_2 


\section{Who Are Australia's Contemporary Craftspeople and Designer Makers and Why Do They Make?}

From the outset, an important part of the research project was concerned with capturing the key moment when makers sought to make the move into professional practice. There were a number of reasons for this. Certainly, it is recognised that further research into the graduate career outcomes of arts and humanities graduates is important and essential (Cunningham and Bridgstock 2012; Bridgstock and Cunningham, 2016; Brook, 2016a, b), especially as more and more students enrol in creative degrees, and universities market these attractive offerings heavily as a gateway into creative industries employment. A significant part of our concern is to generate knowledge to inform educational approaches better able to support ongoing graduate wellbeing, given that arts labour markets continue to experience growth despite persistently low and often declining levels of sustainable employment.

The multi-year Australian Research Council funding enabled us to attempt to capture graduates' early experience of establishing themselves in creative work through a three-year longitudinal study of a cohort of creative graduates in New South Wales (5), Queensland (2), South Australia (11), Tasmania (3), Victoria (7) and the Australian Capital Territory (5). As stated in Chap. 1, before being asked to participate in the study, the members of this cohort were identified as graduating students from publicly accessible graduate exhibition marketing materials and catalogues. This research activity, which builds upon and adds depth to existing Graduate Destination Survey data, was designed to identify the current education, training and professional development needs of Australian creative producers within the larger context of the need for lifelong learning in a rapidly changing economic and social landscape. By undertaking semi-structured interviews with graduates every year for three years, the project was able to capture some of the complex decision-making underpinning this critical moment in professional development. Many of these findings, as well as their repercussions for education, training and practitioner support, inform Chaps. 3 and 4 of this book.

Within our cohort of research participants, both emerging and established, we found a wide variety of interests, areas of practice, life and work experiences and career development motivations (see Tables 1.1-1.3 in Chap. 1 for a summary of participant age ranges and areas of practice). But across the wide, rich and varied personal stories people shared with us 
through the four years of this nationwide study, two specific trends clearly emerged. Firstly, although making a decent income to support themselves and their families or to at least break even on the making itself was a logical incentive to pursue their creative business or self-employment, few if any interviewees indicated that they were motivated by an entrepreneurial desire to 'get rich' or 'make it'. Rather, they provided a number of reasons for pursuing creative practice. Making money was certainly a part of the stimulus, but not the main one. Although (enough) money is obviously important, people's stated emphasis was much more upon making 'enough to get by'.

It is important to acknowledge that this was not infrequently expressed within the context of the interviewee being able to contribute to household income while not bearing the burden of being the main breadwinner; this was especially the case for those taking up or returning to craft or designer maker careers after having children. But as we have written elsewhere (Luckman 2018), across a range of life experiences respondents were more likely to refer to not wanting to get 'too big' for fear of losing contact with the actual making that they love. Becoming too large a business came with expectations that making would have to give way to management and administration and associated concerns over the responsibilities to others entailed in becoming an employer on a significant scale. Therefore, what strongly came through from our interviews was the persistence of what we refer to as the 'more than capitalism' values of arts and creative practice: 'doing what you love', a belief in producing art as a worthy activity unto itself, a commitment to ethical production and consumption as part of an 'intentional economy' that seeks to use its business practices to address social and environmental problems (Banks 2007; Gibson-Graham 2006) and simple human desires for 'good work', with preferably a degree of security (Hesmondhalgh and Baker 2011).

Secondly, one of the standout findings from the research was how often people connected their current interest in making to positive exposure at an early and impressionable age. An overwhelming number of our research participants strongly associated childhood proximity to the tools and processes of making with inspiring them either to pursue craft or design practice or - at the very least - to make it possible through a lack of fear around 'giving it a go'. Often this early familiarity with making arose through either the work or recreational practice of family members. Early educational experiences were likewise formative for many, reinforcing the ongoing importance of arts, crafts and design within the $\mathrm{K}-12$ curriculum in 
any country that aspires to nurture a workforce that can make things. In this way, the creative personal journeys articulated by our Australian research participants mirror findings elsewhere that childhood experience is an important part of the ways creative workers construct their personal and professional identities and map a continuity of personal narrative across what otherwise is most likely a much more complex life story (McRobbie 2016, 79; Taylor and Littleton 2016). Taylor and Littleton (2016) moreover interpret these retrospective accounts as a form of validation for a claim to be a creative person. For this reason, much of the discussion in this chapter explores how a larger sense of history and identity informs and motivates the contemporary craft and designer maker practice of interviewees.

The next section of the chapter offers a little more demographic background to the research study sample within the larger context of research into the career trajectories of craft practitioners across the Global North. This is followed by a deeper drilling down into how the makers we spoke to connect their current identities to formative earlier familial and educational experiences. Finally, the study is situated analytically within critical scholarship on the values of crafts-based practice today as they sit alongside the rise of neoliberal individualised work practices, including the normalisation of self-employment and microenterprise, with all the associated personal financial risk-taking this entails.

\section{Makers: 'Old' and New}

In this study of who are Australia's craftspeople and designer makers and what motivates them, it was striking how many of the recent graduates were not the 20-something straight from school university graduates we naively presumed they would be. Although school leavers (give or take a 'gap' year) undoubtedly still make up the majority of undergraduate enrolments in arts, craft and design degrees, a sizeable minority of students in undergraduate and (notably) honours and graduate diploma degrees were middle-aged or older. Even acknowledging that mature graduates may be more willing to participate in a research study for a number of personal and cultural reasons, their strong presence in our ' 1 -Up' (first year) cohort was notable for what it says about the very real challenges of building and maintaining a sustainable creative career and how this is gendered (both to the advantage and disadvantage of women as mothers). It also speaks profoundly to the powerful attraction of making and how this desire can persist over decades. 
Given this demographic spread, in exploring the complex ways craft and designer maker careers can unfold across people's lifetimes, it is useful to reflect on the profiles of practitioners developed in the report, Craft in an Age of Change (BOP Consulting 2012), commissioned by the Crafts Council, Creative Scotland, the Arts Council of Wales and Craft Northern Ireland. Four key pathways into professional craft practice were identified:

- Craft careerists: committed to the idea of craft as a career, they move to start their businesses shortly after finishing their first (or second) degrees in craft-related subjects.

- Artisans: do not have academic degrees in the subject but nevertheless have made craft their first career.

- Career changers: begin their working lives in other careers before taking up craft as a profession, often in mid-life.

- Returners: makers who trained in art, craft or design, but who followed another career path before 'returning' to craft later on. (p. 5)

This breakdown is highly valuable in examining Australia's craft and designer maker career paths, and each of these categories of maker is certainly reflected in our study, pointing to the complex make-up of the Australian craft and designer maker community and its countless individual, social, cultural, political and economic driving forces.

In reflecting on the participant stories we heard and acknowledging the particularly strong presence of clearly identifiable returners among the 1-Up cohort of makers, what is notable is how few clearly defined craft careerists or even artisans were present, even among the more established makers. This is not to say they were not present, and indeed, many established makers expressed the generational sense that it had once 'been easier', with more arts grant funding. Nonetheless, even among those respondents who have clearly gone on to have outstanding creative careers, the realities of getting to this point are never as straightforward as professional public promotional biographies may indicate. This is an incredibly important point for emerging and mid-career makers to be aware of as they pull together the various strands of their portfolio careers, all the while seeking to build the proportion of time they can justify dedicating to the creative practice side of things. If the findings from our study are any indication of wider trends, not moving directly into full-time creative employment can be seen as a strategic move towards that goal, rather than the end of one's creative dreams (see Taylor and Luckman (2020b)). Teaching creative practice, especially, has long been a key way in which craftspeople and 
designers seek to supplement their creative incomes and stay close to their practice. However, in this age of online marketing and personal branding (including presenting a 'good' life story), the 'downs' of even successful careers can become lost in the requisite positivity of focusing on the 'ups'. These kinds of issues will all be explored in much further detail across this book, but in this chapter, for the purposes of exploring who Australia's craft makers are and what motivates them, we draw upon the rich corpus of interview material the project collected to get a sense of the lived complexities of pursuing a creative career. This includes how issues of stage of life and moving between jobs and careers (often while seeking to build one's own business) emerge in our study as almost the standard career trajectory for Australia's craftspeople and designer makers, though undoubtedly appearing more widely as a new normal in the contemporary workplace (see Taylor and Luckman eds. (2018)). This is exemplified by the many people best identified as career changers and returners.

\section{Career Changers}

Feature Interview 2.1. Female, Jewellery, Established Maker (Interviewed November 2016)

'It was a massive tree change. ${ }^{1}$ So my background is science, so I did a double degree in biology and public health and then spent 10 years working in the corporate arena and private industry, in public health and safety and then to government. And then I converted across into more of this designery artsy business side of things. So completely different, completely and utterly different from my day job that I was doing previously. So it was very much, "I've got to get out here, this job isn't what I imagined it to be, I don't know what I'm going to do with my life, I don't like this job and this is meant to be a good job in terms of what I did my degree in and on paper it looked fine and great and why wouldn't you be happy?" So I found the job very stressful so I started doing the beaded jewellery and some of the handmade jewellery. And I found there was a lot of joy coming from the hobby and by doing a hobby that became more exciting for me. I couldn't wait to get home so I could start making some more jewellery pieces. And it wasn't until I actually sold my first jewellery pieces, I went to the local market and had a little stall 
(continued)

[and] thought I wouldn't sell a single thing, but at it I sold quite a lot and I was quite impressed and shocked by it and then that gave me the drive to be, "Oh people actually want it, they're actually interested. Well if they're interested I should make them, make more and I should do another market". [At] that point there was never: "I'm going to quit my job", it was just, well this is fun and this is the thing I can do on the part-time on the weekend. But then it got to a point where I was probably doing a full-time day and then maybe 2, 3, 4 hours at night-time, depending on what was needed to be done. And I could see that it was taking up a lot of my free time and I could see that I was getting almost a steady income from it $[\ldots]$ that's when I started thinking, well if I can get this level of an income, working and a full-time job and doing this part-time, surely if I put more effort into it and started treating it like a real business as opposed to a hobby, I can help it grow a bit more like this. And then when a time comes and I'm making a certain financial income from it, a certain increment I spoke with my husband about it that, at that point that would be the time that I can leave the business, leave the full-time job. So I gave myself a 12 -month plan as to when I wanted to leave the full-time job and what financial goals I had to hit in order to, to make that transition.'

Throwing in a 'day job' to pursue one's dream is a clearly established romantic aspiration prevalent in the hearts and minds - if not practiceof countless numbers of people across the Global North. Given the mainstreaming of small-scale interest in craft, often handmaking, as part of this current third wave of renewed interest in craft and making, such narratives have become so normalised as to be featured in everything from bank marketing ${ }^{2}$ to feature weekend newspaper articles ${ }^{3}$ (banks do not make advertisements supporting such activity if they do not think there is money in it). What emerges in these media depictions and what clearly enables this kind of growth of this sector of the economy is an increasing number of middle-class and generally (but not always) middle-aged people who, having had well-paid jobs and with most likely some equity in their own home, now in mid-life have enough capital behind them to reconsider their income and lifestyle options. Re-evaluations of what 
really mattered to them and what might be financially possible were reflected in the study:

I grew up with Mum sewing, making our clothes and just being really crafty. We always made things at home, whether it was out of fabric or leaves [...] I nursed for 17 years but in amongst that I was always kind of making things and really interested in fabric and patterns and colours and I had my own tiny little fashion label when I lived in Brisbane probably—maybe 15 years ago. So, I was just doing casual nursing through an agency and had my own little label and I used to just screen print on really small pieces of the finished garment, I'd find a little section to screen print on, and I remember I used to fly to Melbourne [from Brisbane] and literally just walk the streets looking for stockists. [...] Then I moved to Melbourne about 7 years ago-[I] was working at the blood service as a nurse consultant and was just miserable. It was not the job I thought it was going to be. [So] I just did some research, found RMIT [RMIT University] and the textile design course and quit my job, enrolled full-time into study and learned to live without a lot of things that I didn't really need and couldn't afford anymore. [...] Dad had his own business as a woodworker. He used to make furniture from recycled timber way before it was cool and happening. [...] Mum and Dad both worked in the business. He did a lot of restaurant fittings and made furniture, but a lot of people didn't quite get the whole using recycled timber and now everyone's doing it and Dad's no longer doing it which is such a shame. [... I learnt a lot] just watching Mum and Dad work really hard and having to save really hard and kind of living a bit frugally, because of running their own business so it's not a new thing. (Simone Deckers, textiles, established maker, March 2017)

\section{Similarly,}

I had four children. [W] hen I had two out of school I asked my husband if I could do the shoe course. He said 'If you can bring home the same money as you're bringing home now [in your non-creative job] and study full-time go for it' because we had four kids at private schools. So I-yeah I studied full-time, and worked part-time and brought up four kids. (Rose Anne Russell, shoemaker/leatherwares, established maker, April 2016)

This second extract is interesting in that it presents perhaps not your typical picture of someone keen and ready to change career. For some makers, no longer having to focus upon the responsibilities of supporting children freed them up to be able to make the riskier financial choice to give up paid 
employment to pursue creative self-employment. This pattern emerged more strongly among the returners (to be discussed shortly). Rather, what emerges in our study is that choosing a career change can happen at any stage of life. Arguably, it reflects the increased precarity of the job market anyway, especially for younger people. When permanent full-time employment is becoming rarer and harder to get, self-employment is no longer the 'risky' option it once seemed. It is not, therefore, just middle-aged 'empty nesters' seeking a creative career change. These findings - that younger people are also choosing artisanal work as a less secure but more rewarding career change-reflect studies elsewhere, such as in the USA (Ocejo 2017, 149). For the reasons of increased precarity, job-shifting and insecurity already noted, some younger people are attracted to making this shift. It is hardly surprising, considering the growing employment insecurity, coupled with the growing normalisation of entrepreneurial discourses through society and the emphasis on self-employment and microenterprise as standard employment options within university creative degree programmes. ${ }^{4}$ Thus we ended up interviewing many people who did not have an education rich in the arts, yet, despite this, they are now running a creative enterprise. In most instances there was often an event in life that was a catalyst for them to focus on developing their crafting/making enterprise (Fig. 2.1):

[I] worked for seven years as a Speech Pathologist, did two years here in Tassie [Tasmania], two years in the UK, had my daughter over there, so then came back and was only working part time after I had her. And my husband came back, couldn't get a job, so we were quite poor. And so, my sister-in-law is very crafty and taught me how to make-just make a few things that she was giving away as gifts. And so, I just kind of started making things and realised how much I did like making, and started giving them as gifts, because we didn't have a lot of money. And then people were like, "You could actually probably sell this", and I thought, "That sounds fun." And a market came up so I applied, and sold stuff before the doors even opened. Did another market and got picked up by a stockist, did another market and got picked up by a stockist. And within 9 months I was like, "I'm out of speech pathology, I'm going to pursue this", which in hindsight, I don't know that I'd have the guts to do it now, because it was such a big gamble, but I also really didn't like speech pathology. And that's where it started from. And I think because I wanted it to be successful I sought every possible way to make it successful, because I was passionate about it, and it happened. (Helen Mansbridge, Pila Pala, homewares and jewellery, established maker, February 2017) 


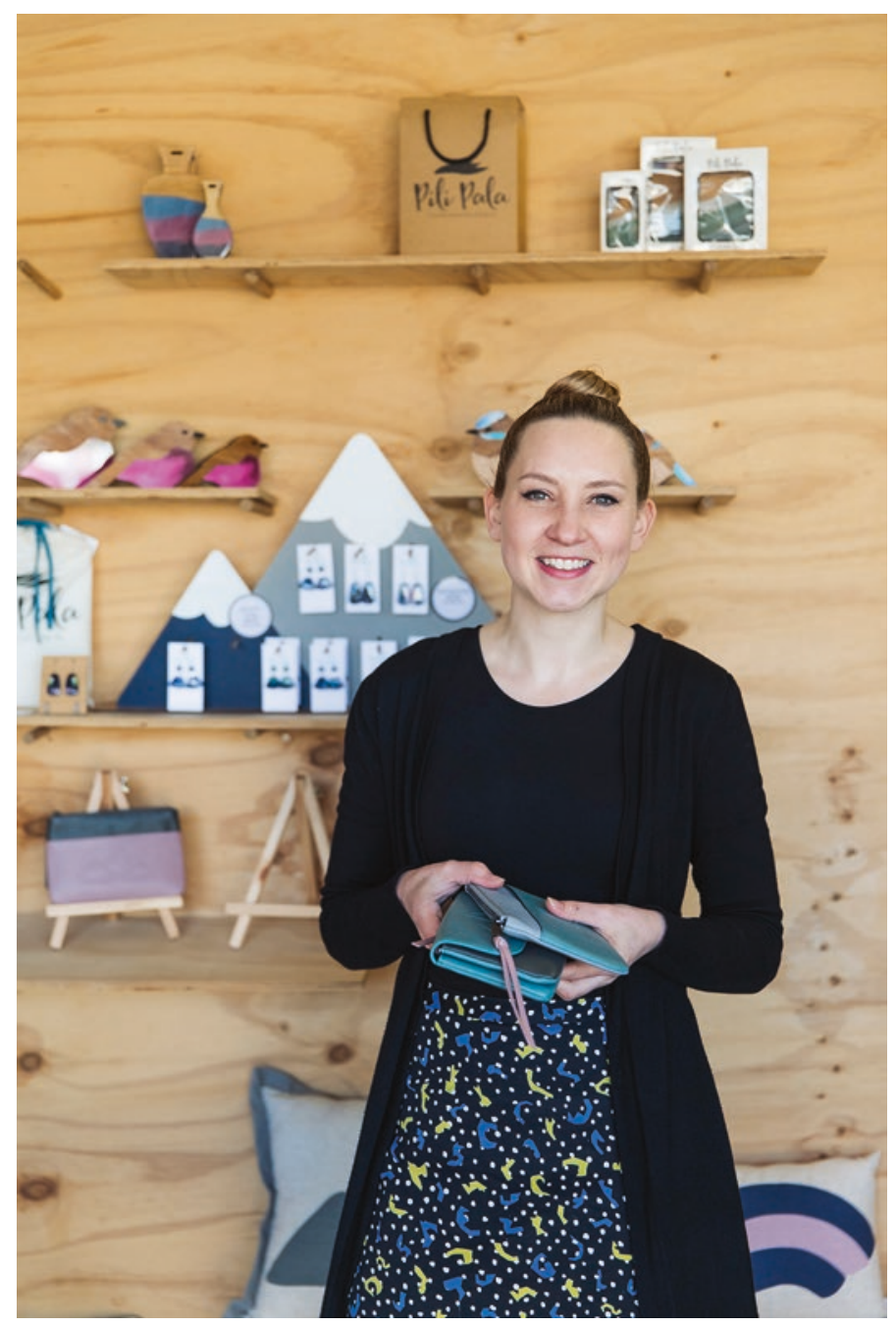

Fig. 2.1 Helen Mansbridge in the shopfront of her studio. (Photograph: Rosina Possingham Photography)

In the Australian context, the not insubstantial cost of quality childcare and the patchy-at-best approaches (in practice if not policy) towards family-friendly, flexible employment options was also a prompt for many 'career changers'. Unsurprisingly in this context for quite a number of our 
research participants, almost exclusively women, starting a family was the life event that precipitated the stepping back from paid employment outside the home and the shift (rarely immediately, but rather eventually) to starting up a craft or designer maker enterprise:

We moved from Newcastle on the east coast to Perth, and my job was in Sydney, and so, and then when we moved to Perth we didn't have any family, so I was looking for something that could be flexible that I could do around the kids, young children, at that stage. So I was looking for something that was flexible. So I was doing some consulting and I was doing the sewing on the side. So I love that, I've always loved that creative thing, creating something from new, and so that was more of a hobby, and then when I came to Perth I couldn't find any high quality market, so sort of out of frustration I thought I'll just start my own market [...] and I started a market more to sell my own kids brand, not as a business but as it turned out there was lots of other people that wanted to sell their products as well, and there was lots of people who were interested in buying it, and so then it sort of became a business. (Justine Barsley, Perth Upmarket, November 2016)

2005, so that's when I started my ceramics because my little one was one [year old] and I thought 'well we're not having [the] separation anxiety that I had with my first [child] going into a creche' and I thought 'oh, what will I do? I will just go and enrol myself into a pottery course.' I heard there's a really good one here in Ballarat. [...] at that stage it wasn't even about income. It was just an absolute love of creating I think and creating something from nothing that's what it felt like, and it just felt so engaging and responsive and then someone likes it-they want to buy it and it's like 'oh I can make a living from this' and of course it depends how high you want to live as to how successful it is, but I think I am starting to gain that more confidence in my work and what I'm creating and then getting it out there, and obviously the kids are getting older now and I can do this now. It's exciting. (Kim Haughie, artist potter, established maker, July 2017)

It is worth acknowledging that while women as traditional primary care-givers were primarily impacted by the demands of family requiring them to seek out alternative income-generating or, notably in our study, identity-giving (Luckman and Andrew 2018) 5 employment activity, a few couples jointly sought out creative self-employment as a means by which to be more available to family: 
Male 'It's certainly more a lifestyle choice than a financial one.'

Female 'Yeah well, we both talked about when we were, you know, when they asked you what you want to do at the school, I mean both of us always said "artist". So it's kind of like been a lifelong goal really for both of us, to be practising artists, so that's just, we're doing what we want really.'

M 'Which wasn't the most, wasn't the kick start, you know I got told to sort of grow up really and find a proper job when I was at school. But I mean that was the mid-'80's, so when I said I want to be an artist they sort of laughed and went, "Yeah but what do you really want to do?" So it wasn't until I was pretty much, hit nearly 40 that I actually managed to start believing that we could do that as a living.'

F 'Yeah and it is a lifestyle thing, we like to be able to pick our kids up and they definitely like it. So it is a lifestyle choice, we love our lifestyle yeah, we're not loaded but we're very happy.' (Small and Pickering, metal sculptures, established makers, May 2016)

\section{Returners}

Another notable finding from the project was the clearly gendered trend among craft returners that developing their creative enterprise was made possible by their children becoming independent adults:

When I was a very young teacher, probably in my early 20s, I trained in Vis Com [Visual Communication] or graphic design back in the day when we didn't use computers and I think my art practice has always been sort of [a] fairly neat, tidy, clean, precise sort of thing. So I never really found a home in painting or sculpture or some of those sorts of things, although I did like print making. And then in my first few years of teaching I just went to, it was an after-hours hobby class type thing that was run by one of, at that stage, Melbourne's sort of leading jewellers. He just set up a studio with half a dozen benches and invited people in. So I spent a couple of years just exploring that and realised that now I had found [something] which suited my creative approach and my skill level; it was sculpture but it was neat and tidy and it was little and it was precise and it was sort of quite engineered. So I did that for a few years and then had children, which I don't regret at all, but I packed up the tool box for a significant number of years and just put myself on a promise that when I could I'd come back to it. So it took me probably close to 30 years to get back to it. The toolbox sat there and the kids used 
to look at it and go, "Can we look in your tool box?" Which is pretty funny. And then I was with the Education Department in Victoria and had the opportunity for early retirement and decided now is the time. [...] So then I enrolled at NMIT [Northern Melbourne Institute of TAFE, now Melbourne Polytechnic] and thought I'd died and gone to heaven. (Alannah Sheridan, jewellery, emerging maker, March 2016)

So, on the upside, for most of the people in Alannah's position, being able to return to their practice was often also enabled by their household's finances being set up in such a way that they could explore creative possibilities while not also having to worry too much about making an income from doing so. This was especially important for those returning to study, though for many this was not without its challenges as they, like many of their fellow students, sought to balance study with part-time work. But perhaps more poignantly, as we see in Alannah Sheridan's account, the return to craft practice requires, by definition, an earlier experience of having to initially give it up. Others shared Alannah's experience:

Yes, so there's a story. So really maybe like a lot of crafters, you know my background is I went to uni, I did a visual arts degree and then journeyed off to do the teaching thing and then had kids. So I was at home and two friends had kids the same age so as an excuse to get together without the kids we had a craft club which sounds a bit daggy but my girlfriends were big sewers and they always had the beautiful retro patterns which I love but I can't sew, and I was, oh what am I going to do and then, I don't know I just, the wall paper thing came to me. So it started you know as just doing gift tags, and then I discovered these flying ducks, so I started doing the flying ducks and then I really like Betty Jo designs. I don't know, do you know Betty Jo with the, she does stuff out of lino, and she was doing beautiful birds. [...] I was an art teacher, high school art teacher. And then for a while I was at the Cairns regional gallery as their educator, yeah. So I've always been in the arts industry, but not actually making my own stuff. So it's really nice now to get back to what I went to uni to do, you know I went to uni to be an artist so yeah, so it's nice to arrive back at that point. (Sage and Peppa, homewares and jewellery, established maker, November 2015)

Again, it is important to hear these stories. We know that not all current students and recent graduates will be able to move into creative practice in the years immediately following their formal training. But in an employment market that demands of most participants an agility to move between not only jobs but even different sectors and skillsets, that return is possible is an important message. 
The recent growth in both the online and face-to-face market for the handmade, which presents a number of opportunities not previously available to makers, clearly contributes to the feasibility of returning to creative practice. Whether or not this market has yet peaked remains unclear, but what is evident is that it is fuelled by more makers than can make a sustainable living from it. How people make their own personal peace with this situation and negotiate their financial place within the market remains one of the most profound challenges facing Australia's craftspeople and designer makers. How this marketplace is impacting the educational approach taken towards craft and design education and how it is impacting contemporary careers will be explored further in Chaps. 3 and 4 . But before there is demand for entry into creative undergraduate degrees or a commitment to pursuing creative self-employment, there are moments of self-realisation to be had and a series of choices to be made. In the next section of this chapter, we will be stepping back from journeys delayed or returned to in order to explore what set people on this track in the first place.

\section{Enabling Ecosystems and Family Making Histories}

\section{Feature Interview 2.2. Female, Ceramicist, Established Maker} (Interviewed November 2015)

'Yes, I'm quite sure that that's what led me down that path, and I think, for some reason when I was younger I often used to not like the comment, "oh are you creative like your parents?". It used to really frustrate me, but at some point I think I just had that light bulb moment in high school where I was having to choose my subjects for my senior year and you know at 15 you really don't know what you're doing. But I suddenly thought, oh I don't need to do maths, I'm going to be an artist, and it was, you know I think that was probably my first realisation that I had that leaning and I went on to start a fine arts degree when I finished, graduated high school, but I left it in the second year. [...] And my parents, who'd been doing art as long as I can remember, I mean it wasn't their first career either, my mother was an occupational therapist, my father was a civil engineer. So he retired when I was about ten or something from that completely and opened an art gallery and picture frame business in town. And my

(continued) 


\section{(continued)}

mum worked full-time as an occupational therapist then so that was how the rest of my childhood went was with Dad being at home and Mum being at work. And in that time Dad got more and more into ceramics and then they both got right in to that, so by the time I finished school I'd worked for them for years in their studio doing their commercial lines from probably the age of ten really I was doing ceramics. So it was always just a job for me and my brother you know, it's what was there and it was our first job and sometimes we worked in the gallery for them too. [...] And I think that working for them gave me a model of a successful business, [...] So I've had a good broad education and I think really my education arts has come from the experience of being in this active workshop from the age of ten and learning about it from a really young age and ceramics is an incredibly technical field to get into, you know. [...] And I realise since then as I talk to other ceramic artists, most of them do a diploma or a degree or whatever, and then you're on your own. Like you're really, you know you might have a local club but [...] the investment of a kiln is massive and to understand what's going [on] when you pull out a load and something different has gone on, I have this just wealth of knowledge in my mum and dad, I can turn around and go, why has this happened, you know, and even though the clays and the glazes I'm using are quite different to what they do, you know you can usually shed a bit of light and he's got a lot of resources there that he can offer me too, reference books and stuff that we look stuff up. So it's, I think without that it would be incredibly discouraging, there's so much testing and experimenting with ceramics.'

\section{Family Making Histories}

I made my first button-up shirt at the age of 11, and I have not stopped sewing since. I've got two sisters. When we turned 21 we all got the choicedo you want a big party, or do you want a sewing machine? So, we all went for the sewing machine. (Robyn 'Boo' McLean, custom textile design, homewares and accessories, established maker, July 2016)

I always got into trouble as a child because if the scissors or the sticky tape was missing, it was me! (Female, jeweller, established maker, February 2016) 
The previous discussion, much like the majority of each interview itself, was concerned with where people are at now with their making and, especially in the case of the 1-Up participants, where they want to be. Another key finding in this study was the connection between wanting to pursue making as a living and early childhood exposure to it. This was identified as playing a formative role in the desire to do creative things. Markedly, having direct family experience of running a creative business (which by its very nature tends to include participation in the business) was arguably what enabled some of our makers to move more directly into being ready to run their own economically sustainable business (see Feature Interview 2.2). Many of the apparently most successful and stable, and certainly happy, makers we met around the country had this kind of background. What is notable among them is that unlike many graduates, they knew they had to 'hit the ground running', seeing their creative practice as a business, and thus figuring out how to balance their more creative or original making alongside 'bread and butter' production lines or some other regularly profitable output. Having been brought up around people familiar with twentieth-century studio craft models was thus a clear boon; the 'alternative' children of 1970s 'hippies' can make for savvy artisanal business people. Such levels of sustainable practice were especially palpable and commented upon by those whose vision of economic 'success' operates alongside materially moderated lifestyle expectations, with a focus on quality of life including time for family. Not surprisingly, many of these research participants lived in regional locations, still close to major cities, but without their high housing costs, and with the bucolic lifestyle affordances of rural or peri-urban living. Knowing how to negotiate these trade-offs, and a personal value system structure that supported doing so, was frequently connected to their early family experiences.

Feature Interview 2.3. Minna Graham, Ceramicist, Established Maker (Interviewed July 2017)

'I don't think I ever had a choice, if I'm really honest with you, I think it was inevitable. I think just growing up the way I grew up [...] my parents, they would just live and breathe for art. My father passed away in 2000 , my mum's very much alive, she's really eccentric $[\ldots]$ in a most fantastic way, I can't describe her, she's just the most wonderful person and everyone that ever meets Jacquie just, just swoons. She's, 


\section{(continued)}

she's an incredible lady, incredibly humble, has no idea how wonderful she is, really no idea, but she's just really fantastic in everything she does, her every waking minute is about creating something in some way. So she makes all her clothes, she hand spins wool, she knits her own jumpers and dyes it herself. She just makes everything. Her house is painted bright pink on one wall and halfway through she, well more than halfway through she ran out of pink so she started it in blue. So when I was growing up, the house I grew up in was a very, very old dilapidated farmhouse that one of my dad's art students (because he was a teacher as well) said (we were looking for somewhere to live, we'd just moved to the area). And she said, "We have this old farmhouse you can, you can rent it 20 bucks a week". So we lived in this old farmhouse for my whole childhood that we rented for, I think we were there for over 20 years for $\$ 20$ a week and they just did what they liked to it really. So Mum had painted on the outside of the house one whole side of the house was a giant fox, multi-coloured fox, another side there was an ant, massive bull ant, there was a, it might have been a possum. So each side of the house had different animals on them. On the inside around the doorways were [...] really bright coloured patterns, criss-crosses, and polka dots and each door was painted with all sorts of crazy patterns. [...] My dad had this amazing floor-to-ceiling bronze sculpture based on the Opera House that he'd built- that was in our lounge room. There was just no spare wall anywhere and just little bits of squashed metal were art pieces and they'd be hung on the wall and it was just nuts so. [...] We just lived out on a, on a sheep station that wasn't ours, we just rented this old farmhouse. So just out in the middle of nowhere, really free and it was great, it was a fantastic childhood. My father was a Head of the Local TAFE [Technical and Further Education] Art Department so he taught everything. He taught sculpture, life drawing, print making, my mum's a print maker predominantly. So she did a lot of, she was really involved in the printmaking side of things as well and painting actually, she did painting classes as well, they just did all sorts, $[\ldots]$ I went through a phase when I was a teenager just hating art. [...] I think that probably the most valuable thing that came from all that is resourcefulness. Both my parents are extremely resourceful and we just made do with whatever we had, there was never much money because we're a family of artists. You have to make do with what you've got.' 
Clearly, parents, grandparents or significant adults have played a catalytic role in many maker's lives, enabling and inspiring the development of their creative passion. For some, such as in Feature Interviews 2.2 and 2.3, this was in a specifically identifiable arts or craft practice setting. But such exposure takes many forms, such as simply watching or working alongside parents or grandparents in their sheds, home offices, sewing rooms or kitchens:

Yeah well I guess I come from that long line of women who have always crafted. So my grandma would crochet and knit and sew, and my mother as well. It wasn't considered a career path back then but I always as a child [was] learning how to knit and crochet and sew and patchwork, and my mum still does that now. My dad was always, he was one of those tip scavengers who could go out and find...yeah find bits and pieces and just make something out of nothing, and they were both really really good at that and I guess that was a really huge influence as well. (Kim Haughie, artist potter, established maker, July 2017)

My father was an architect but he also pursued Chinese ink painting and I grew up in a house where he had his practice on one floor of the house and in his room he'd have his painting studio and on one side it's all computers and clicky clicky and then on the other side it's the traditional smell of rice paper and ink which is very nice. (Chere De Koh, textiles, emerging maker, December 2015)

I grew up around boats and my first dream was to become a yacht designer. So copying boat plans out onto taped together A4 sheets of Reflex, and just a love of drawing some technical drawings. And Dad always had a halffinished yacht in the backyard, and so working on that. So I think they were the first seeds of wanting to do something in design and making. (Scott van Tuil, furniture maker and product design, emerging maker, February 2016)

My dad was a bit of a hobbyist maker. He made model ships and he used to paint a bit too. So yeah, he's probably the creative one. My grandmother always did her embroideries and Mum used to sew. So there's that, those sorts of connections. [...] I remember Dad sitting at the kitchen table (no workshop in those days) with his balsa wood and he'd just have the plans there and he was sort of, he'd make half of it up and then he'd make these incredible model ships with very, very fine little cannons and all the fencing and Mum would have to sew up the flags. Then she'd complain about Tarzan's grip everywhere on the table or on his pants, because he just did it on the kitchen table. So yeah, I obviously, that would've had a big influence on me I think. (Julie Blyfield, jewellery, established maker, August 2015) 
Furthermore, for many of our interviewees, although their parents were not themselves either professional or hobbyist artists or craftspeople, they were creative in other ways, such as in their approach to life, an attitude of resourcefulness or a hands-on hobby. These were people who could and did repair, 'make do' or 'tinker' in their shed. They had the skills to support an attitude of self-sufficiency. Unsurprisingly then, early making and often designing experiences and exposure were particularly commented upon by those who grew up on farms, situating contemporary Australian craft and design within the larger history of making innovation through often rural tinkering (Wilson 2017). Other research participants gained creative insight and inspiration through their parent's work or professional pursuits such as building, engineering, architecture or inventing.

I came from essentially a making family; my dad's a tradesman and I've been building things in the shed ever since I was 5 . (Male, homewares and jewellery product designer maker, established maker, August 2018)

I was definitely supported by my family in terms of kind of creative and artistic pursuits. My mother's very arty and crafty, and my dad's also very practical. He was a carpenter, so that sort of problem-solving practical hands-on work sort of comes from both sides of my parents, and it was always greatly encouraged, so the whole thought of going to art school, as opposed to, say, any other form of study was definitely encouraged. (Meredith Woolnough, embroidery, established maker, June 2016)

Others were also fortunate to grow up in rural or frequently more progressive peri-urban locations, including Claire Beale whose parents sought out the 1970 hippie version of the still highly desirable 'move to the country' dream with its strong associations of environmental responsibility and self-sufficiency:

Oh I would say that I was incredibly lucky and grew up in a creative environment, so I knew that I was going to be involved in some form of creative practice from my very early childhood. I grew up in a collective, well not really, my family were part of a group of friends who lived in the Yarra Valley on acres of bush, so we owned 9 acres, our neighbours next door had five acres and so on and so forth. And everyone that was living in that environment were creative practitioners of some sort, they were primary school and high school teachers but they were also ceramicists, fashion designers, artists, jewellers, a whole range, it was the real ' 70 s alternative lifestyle creative 
environment. Didn't mean that we were a commune by any sense of the word because we still have very established separate family identities and monetary things and all those things. But I grew up in an environment where we were just encouraged to be creative and make, and so having extended family who was a master potter you'd go and play on the wheel, the next day you'd go and play on the tool bench and muck around with scraps of wood and see what you could cut and draft. Probably through an OHS perspective and modern parenting now, the things we did were highly dangerous, but that's how we learnt. So I learnt to sew when I was four, on a sewing machine when I was seven or eight, and I was making my own clothes, I was painting and drawing, so for me it was this is just what you did. It took a lot longer to actually understand how I was going to make that happen, and so when I went to university, and I also felt like I didn't have as much talent as my peers, so when I went to university I said, "I'll do a fine art history degree, that'll be the sensible thing to do", and got a classical education. (Claire Beale, textiles, established maker, October 2015)

The sheer weight of all these evocative vignettes, which represent just a sample of all the stories we heard, makes it clear that for many of the participants in this research study, irrespective of when in their lives they were in a position to dedicate themselves more fully to making as an incomegenerating activity, the foundation for a later relationship with making was established early in their childhood (Fig. 2.2).

\section{Early Material and Tool Knowledges}

This normalised presence of tools and materials and people not afraid to use them is perhaps less significant for the aptitude towards any specific set of skills this instilled and more notable for how it led to a broad-ranging but profound affinity with making something from scratch-and a belief that this is even possible and achievable. Adelaide-based designer and maker, Christian Hall, describes this more existential understanding of how an early hands-on experience of handworking is an empowered, deliberate engagement with understanding and interacting with the world:

I wouldn't call it the start of my career, but I think the start of my thinking as a creative person, I'd kind of mark that very early on. I spent a lot of time on my own as a kid in the bush and was very self-reliant and from a very early stage was given tools mainly by my father to entertain myself and the two that I think that have persisted were tools with language and tools with drawing and imagery. So I'd start that very early on around the age five. [...] 


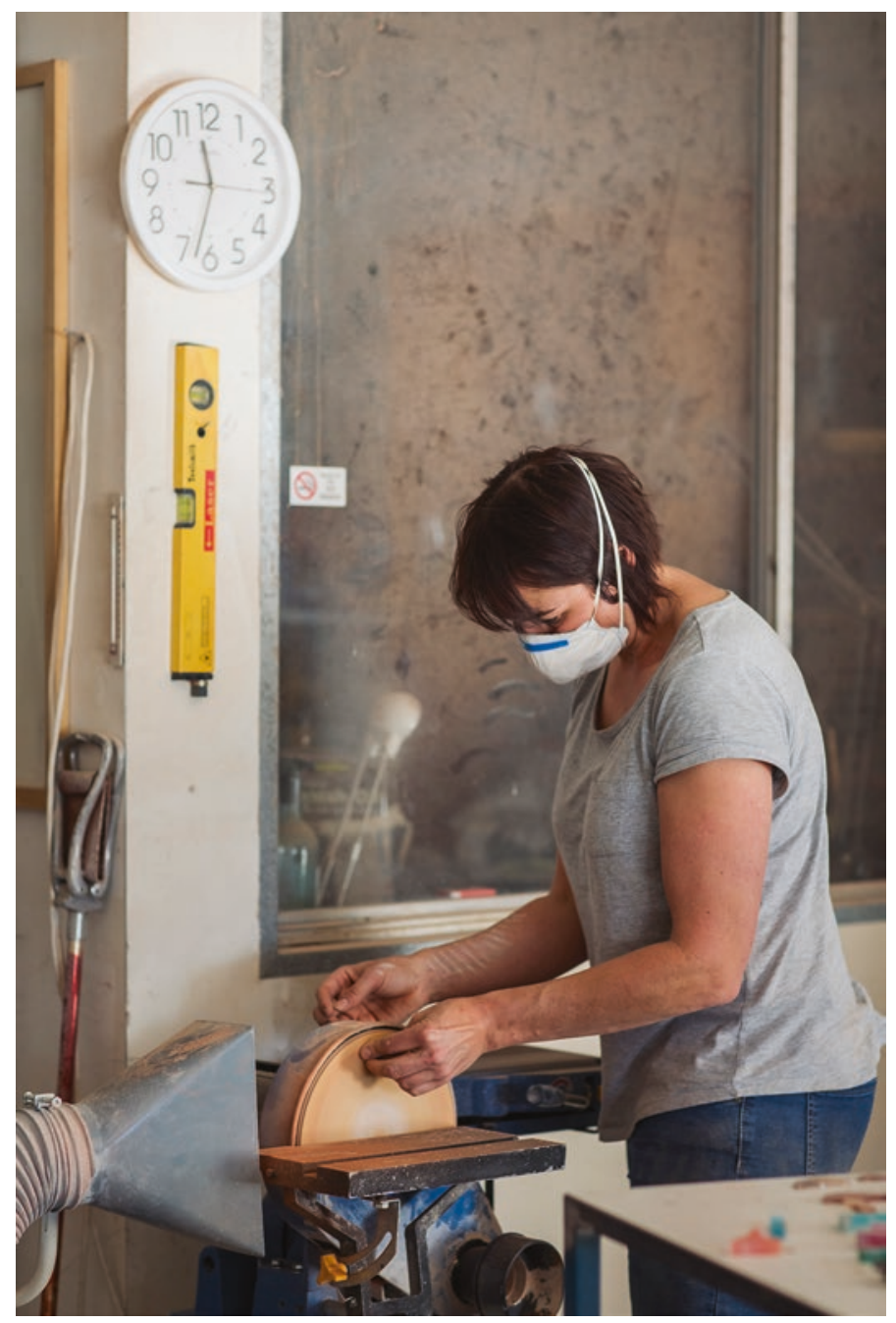

Fig. 2.2 Jax Isaacson, Jax and Co. (https://jaxandco.com.au/) in her workshop. (Photograph: Rosina Possingham Photography)

So for me that's really key and more than thinking about it as an artistic career, it was really the foundations of thinking for me. I remember my father showing me that in order to draw something in a sense which was more realistic you looked at it in a certain way, you looked at it as a series of 
shapes rather than as a continuous outline and so for me that was the first time in memory that I formed a strategy for understanding the world and choosing a way of understanding the world. And so obviously as time went on I learned other ways of perceiving the world, but that was the first time perception became a choice. So I think [...] without that kind of start I don't think I would've pursued [this] career. (Christian Hall, object and jewellery designer maker/industrial design, established maker, August 2015)

These making histories are included here not only for the insights they offer into the motivations of these particular craftspeople and designer makers but to emphasise the essential importance of making in all its forms - amateur and professional — to a healthy making ecology.

The social and economic importance for a country of people who can innovate and value-add raw materials seems all the more pressing in light of an influential and widely quoted 2019 report from the Harvard University Kennedy School's Center for International Development. The report identified the Australian economy as 'rich, dumb and getting dumber' and ranked it 93rd in complexity, behind Kazakhstan, Uganda and Senegal (Patrick 2019). In this context we can see why many of craft's leading thinkers and writers have long upheld the value of amateur and hobby practices as essential to maintaining and growing a country's making capacity. British writer, researcher and lecturer in craft theory and history, Stephen Knott, has recently been at the forefront of research into the significance of amateur making. In an article in Crafts magazine coinciding with the release of his book Amateur Craft: History and Theory (2015b), he cites craft legend David Pye's lauding of amateur making to make the case for its ongoing importance:

However, in the post-industrial world, where the economic rationale for many craft processes and traditional models of apprenticeship have been fundamentally challenged by technological innovation and outsourced production, the continuation of many craft practices actually depends upon amateur making.

As the furniture maker and professor at the Royal College of Art, David Pye observed in his book The Nature and Art of Workmanship (1968), only amateurs could afford to devote the amount of time and resources necessary to sustain many crafts. This is because amateur craft can be economically aberrant, it provides a space for forms of practice that need not pay heed to market concerns. (Knott 2015a, 5l) 
It is not just the capacity of amateur practice to maintain heritage or legacy craft skills for which Knott advocates but also, and particularly, its capacity for innovation and making 'outside the square':

I aim to contest this dismissive set of assumptions, and demonstrate how amateur craft has made a vital and important contribution to the material culture of the modern world, and remains the freest, most autonomous form of making, within structures of Western capitalism at least. Under no financial obligation, amateur craft allows an individual to make something for the love of it alone, without the pressure of deadlines or the need to please a patron. (Knott $2015 \mathrm{~b}$, xi)

As we have seen, it also empowers future generations of craftspeople and designer makers. Making histories of all kinds across the full spectrum of making practice, including amateur and hobby, offer an essential exposure to and experience of both practices (what to do with tools and materials), but more importantly, they engender the 'you can do it' attitude.

\section{The Impact of Educational Encouragement and Exposure}

It goes without saying that the nature of our educational experiences, like our early childhood experiences of family, also plays a significant role in shaping our lives. So too, choosing to send a child to school in education environments supportive of creative making and creative enterprise is significantly influenced by family attitudes and valuing creativity, making and the arts. Perhaps not surprisingly, a disproportionate number of our interviewees attended Montessori, Steiner or other non-traditional schools with a strengths-based approach to fostering and supporting an individual's educational pursuits:

I went to a Rudolf Steiner school and there was a big emphasis there on creativity and drawing and painting and theatre. And I just found that that's where I excelled really, and that began then, and then so from then it became sort of like a strong suite or a, something that I felt, that I felt comfortable with. (Phillipa Julien, textile artist and designer maker, emerging maker, February 2016)

I was talking to a friend recently about our education, and this hadn't occurred to me but she suggested that-for my first 7 years-so when I was young I was home schooled and then I went to a [Montessori] school [...] 
And I was explaining how the average week at Montessori went, and how it was structured. [...] throughout the week you would have formal lessons on different subjects, but you'd also be given a set of tasks you had to complete by Friday or we wouldn't get to play sport (which was devastating-you'd have to continue doing our tasks). And it hadn't occurred to me, but she did suggest that that self-directed way of learning and way of conducting yourself, getting things done, was maybe an influence. And that does make sense, I hadn't kind of made that connection myself. (Corner Block Studio, timber frames and wall art, emerging maker, November 2015)

Others taught in such schools:

So I got involved with the Steiner community because they were very interested in shoe making because Rudolf Steiner had a thing about shoe making. [He believed] all students should learn how to make shoes and they were interested in the whole process, so they did the farming bit, did the tanning, and then learning how to make, how to craft shoes. [...] This is in the UK, so I did a bit of work in a few different Steiner schools and they of course had beautiful workshops so it was sort of easy for me I'd just pile all my machines into the car and trot around the countryside. (Lunaboots, shoemaker, established maker, February 2017)

Reassuringly for those without the family economic resources or cultural histories that may see them attending such an independent school, many of our interviewees cited the influence across school types of a 'great teacher' inspiring and supporting them in the development and pursuit of their creative making. Highly regarded Australian jeweller Blanche Tilden was the fortunate beneficiary of the kind of 'above and beyond' individual acts of support and generosity from a teacher that really can have lifelong impacts, for both parties:

I was at school, a private school in Bowral. They had a really good art department and my teachers, I say I really like, I really want to know how to make something out of glass and she's like, well, how are you going to do that. It was impossible and her husband, independent of her teaching at the art school, was a ceramicist and so she said I think you can melt glass in a kiln, you can try and do something in his ceramics kiln. And then she said I think there's actually a ceramics kiln here and she dug it up, and cleaned it up and she plugged it in for me and I made this kind of big panel out of glass and it was like a nautilus shell. So it was all the kind of sections of a nautilus shell but I didn't understand about compatibility in glass. So if you melt 
different sorts of glass together and they're not compatible it doesn't work. So I made this beautiful thing out of glass and then I went away for the middle of the year holidays and when I came back it was all just like sugar. [...] so it was all laid out and I was ready to put it together with lead, to make it into a big leadlight window and yeah it was all, it all had just turned into sugar. And I was like 'wow, now what do I do that's my HSC [Higher School Certificate] major work?' and so then she went, because of this ceramics connection, she went and she bought me some Bullseye compatible glass. She went and got, I think she went to Sydney and got it for me and she got the information of how to do it and the temperature and the annealing and she figured it out for me. [...] In about 1997 I think, I had an open studio and she was in Melbourne and she saw, and she came to the open studio, $[\ldots]$ She rang me up beforehand and $[\ldots]$ she said 'are you that same [person from Bowral], do you have a piece in the National Gallery?' and I was 'yeah' and she said I'm Mrs Xxxx, your art teacher. [...] And she came to my house and I was crying and she was crying and I say I wouldn't be here if it wasn't for you. So part of the reason I wanted to do this is I've had so many people have helped me, so many people, I wouldn't be here without about 40 different stories like that and I always try and help people if I think they're going to run with it, pass it on, because no one really gets there without help. No way. It's very hard. (Blanche Tilden, contemporary jewellery and glass, established maker, October 2015)

Blanche's is an exceptional (and beautiful) story; few art teachers get to see their student's work in the National Gallery and few students get to personally say 'thank you' as adults. Nonetheless, the early attitude of teachers, including those charged with 'careers counselling', can make or break a young person's attitude towards pursuing a creative career:

I was a creative child and that was always a thing that I was rewarded for by my folks. You know, it was a sketch book-I always had things on the go and I was always labelled the creative one. [...]. So it went from there and I remember really clearly a moment when I was 15 standing in high school looking through one of those career guide things that they don't have any more, I'm sure now because it's so much faster and not traditional, and reading a section in there about interior designers and that occasionally they can design furniture and literally like that bolt of lightning thing of going, that's what I want to do, at 15 . And then I went in all sorts of circles and finally got there but didn't go in a straight line. (Julie Pieda, interior and furniture designer, established maker, August 2015) 
I made a billy cart when I was a kid that sort of thing, [...] like I think everyone has an enjoyment of making in some way or another, whether it's baking some biscuits or drawing a crayon drawing as a kid, or you know, super gluing some pipe cleaners together. Like everyone enjoys playing with something physical, rather than just sitting behind a computer all day. And like that's, especially the case I think with woodwork, lots of people enjoy it and lots of people would be capable of it, it's just whether they've had the life chances in order to be able to go through with it. And I was lucky enough to have people in my family who are interesting in making, and a bit of interest in sort of creativity, as well I suppose, but also having other people through school that were quite encouraging, like two of my woodwork teachers were quite interested in woodwork and they said some really like pertinent things that sort of stuck with me, and one of them still maintains contact now, so I suppose it started — cut a long story short—it started sort of high school, and maybe a little bit before I sort of went, oh yeah I really enjoy this. [... but then] because my vision had degenerated in 2005 and I never thought I'd be able to do it again, and found out about a safety course about learning how to use tools safely as a vision-impaired or blind personor legally blind person - and that sort of, just did a bit of a crash course on that, and then I went and had a chat with Linda at the art school, and she was like totally welcoming and she even went and dropped in and checked out their facility as well to see what sort of stuff they had there, just off her own bat, so she's been an ongoing sort of member of the design community in Tasmania that contributes a lot. (Male, furniture and lighting designer maker, established maker, February 2016)

Before moving on from this discussion of early influences, it is important to acknowledge that although people would prefer to recall the positive influence significant adults can play in their development, we also interviewed numerous people whose intended pursuit of a creative career was strongly discouraged. For some, this transpired at high school when needing to choose between undertaking science-based or arts-based subject streams. Unsurprisingly, a number of career changers reported being variously directed away from pursuing arts study. Across all categories, many recalled influential people in their lives stating things like, 'You can't make a decent living as an artist'. While discouraging, such statements are not entirely unfounded and may well come from parents who themselves pursued creative careers and wish to protect their children from the emotional and financial struggles involved. Again, it is interesting to consider this in light of the cohort of career changers and our argument that a creative career not directly pursued is not necessarily a creative career lost. 
One of our interviewees reported that it was his parents' warnings not to pursue such a career that made him determined to establish his own strong financial base and business acumen pursuing another career, before later in life returning to making and the development of a creative enterprise inspired by his grandfather.

\section{The Values and Personal Meaning of Small-Scale Making Today}

The examples from this study presented so far, illustrating the significance of early influences on future creative careers, parallel research into how people come to embody the disposition to engage in this kind of work. Clearly, following Bourdieu's famous work into cultural production and consumption, we can understand this process of becoming in terms of entry into a making habitus, that is, early exposure to a 'feel for the game' (Johnson in 'Editor's Introduction' to Bourdieu 1993, 5). Through different early family and school experiences of making-some orientated more as an arts practice, others as an economic activity-the makers in our study approach the field of cultural production that is craft and design with a range of dispositions 'which help to lead them to these positions and to define their way of operating within them and staying in them' (Bourdieu 1993, 64). The lived networks of early exposure to and understandings of making can clearly be seen here as being not only highly influential but as directly enabling access to the field of creative production:

The field, as a field of possible forces, presents itself to each agent as a space of possibles which is defined in the relationship between the structure of average chances of access to the different positions (measured by the 'difficulty' of attaining them and, more precisely, by the relationship between the number of positions and the number of competitors) and the dispositions of each agent, the subjective basis of the perception and appreciation of the objective chances. (Bourdieu 1993, 64)

As an important part of this, we can see in many of the extracts above a classic orientation into the art field that requires trade-offs between 'doing what you love' and the recognition and fulfilment that comes from this and potentially higher levels of income that might come from more conventional employment. Choosing the former means being resigned to potentially low levels of income as a result. In those craftspeople and 
designer makers who, as we have already seen, had chosen creative selfemployment as a lifestyle choice and were happy to make financial sacrifices, we can clearly see an instance of Bourdieu's (1993) assertion that the field of cultural production is the 'economic world reversed', that is, a field whose own logics and value structures defy those of the field of (economic and political) power.

The findings in this Australian study resonate with those of a recent British study that similarly employed rich, semi-structured interviews to understand how individuals come to understand their identity as artists. Taylor and Littleton (2016) found that the 'interpretive repertoires' their interviewees employed:

are culturally established and recognizable arrangements of wording and argument, often linked by commonsense association rather than conventional logic, $[\ldots]$ inflected with values and accrued associations. Like other resources, such repertoires pre-exist any particular occasion of talk and can enable or constrain identity work. (48)

This reinforces the key understanding underpinning Bourdieu's work, namely, that the dispositions (including language and narratives) that we use to make sense of our world and inform our negotiations through it are not formed in a vacuum but are precisely the result of our habitus. Taylor and Littleton's (2016) study had a focus on 'early interests, experiences and influences', and in this context they identify three key recurrent repertoires: "prodigiousness", "creative early environment" and "creative inheritance" (48). All three-early talent that is rewarded, growing up in a creative habitus and making as a direct link to family and history-are also clearly evident in our study. Although for some makers these interviews occurred not too long after leaving a family home or even while they were still supporting their creative practice by living with their parents, for most, these accounts represent memories that continue to resonate for them many years later. Makers are thus able to draw upon these memories and dispositions to:

... construct a narrative of continuity from 'who I was' to 'who I am' which functions as a claim to an identity as a creative. In addition, because the claim establishes a narrative where the choice to pursue a creative career follows on logically either from innate dispositions and talents, or from early experience, it can also function to validate a participant's choice of a creative career. $(50-51)$ 
Bourdieu's economic field of power is, of course, still very present here. One of the key take-home messages of the 2016 Australian federal budget (released in the middle of this study) was its emphasis on supporting small business to create jobs growth. This focus upon individualised entrepreneurial risk-taking underpins many governmental policies, not just in Australia, but globally around the industrialised world. Arts, cultural and creative practitioners are all expected to be increasingly business-minded as part of the policy shift signalled by the emergence of an emphasis on creative industries; clearly, the cultural and creative sector is most certainly not immune to wider trends (McRobbie 2016; O'Connor 2016; Ross 2007). But in this way, too, to quote US-based scholar of the cultural and economic persistence of artisanal handmaking Kathryn Dudley (2014), 'Hand builders are focused on actualizing an entrepreneurial self through the performance of a cultural repertoire that is collectively, not corporately, owned' (192), that is, owned largely by the making community, not the government. In this way, as we have written elsewhere (Luckman 2018), arguably most of the craftspeople and designer makers we spoke to in this study speak of their identity and motivations for pursuing their work in ways quite at odds with any identification with entrepreneurialism and growth:

I figure that it's why I love doing it, I actually need to do it, I go a bit loopy if I don't get time up here [in my studio]. I'm not really worth being around according to my family if I don't get time up here. And I figure because of that need to do it, it doesn't matter if I make money, if it can sustain itself, which it does, then I'm happy. So that's my bottom line is, if I can, if it can just tick over and I can afford to get clay and I can afford to buy materials and to fire [them] then I'm happy. (Minna Graham, ceramicist, established maker, July 2017)

When I graduated from furniture school I didn't know how to run a business. So I just shut up and I watched and I saw how hospitality people did it. I saw how hairdressers did it. I saw how small start-ups did it, and I just watched and I tried to get an idea of what would work for us and what wouldn't. And I've spoken to a friend of ours down here who runs a really big successful gourmet food sort of like Vari's [a famous, since closed, Italian deli in Norwood, South Australia] but on steroids, expanding all over Tasmania. They have 250 staff or employees or something. And he was a client initially, now a friend, and we were having a coffee or something the other day and Pete and I were saying about how we're struggling with the 
scale of things but we really didn't want to take on employees or get bigger. And he said he totally understood, that if he had it his way-he's got 150 or 200 staff that rely on him, he spends all of his time doing payroll, basically managing things - he said if he had it his way he'd close it all down tomorrow, he'd have a hole in the wall shopfront somewhere, and he'd have a coffee machine and prosciutto and that's all he'd sell. And he'd work from 9:00 in the morning, no he said probably 7:00-7:00 in the morning until 3:00 in the afternoon five days a week and just keep it simple. So that's kind of what we're trying to do. We're not trying to take over the world. We don't need to have our-we're not trying to be some kind of international cock rock superstar, kind of - that's not it at all. We just want to be able to enjoy what we do, enjoy making stuff for people that we like in the way that they're going to appreciate it, spending time with the kids, living somewhere beautiful. [...] It's about keeping it small and manageable and enjoyable. Because once the enjoyment goes out of it there's no point. (Laura McCusker, furniture maker, established maker, February 2016)

The desire to pursue self-employment as a means by which to 'be one's own boss' - and thus the work-life arrangements that can go with thishas a long and deep history (Dudley 2014; Gill 2014), and it is an ambition clearly not limited to craftspeople and designer makers. Such sentiments also clearly precede the current government policy and wider social interest in entrepreneurialism. But even in this contemporary context, the values and the meaning of small-scale making today are perhaps not as anomalous and out of step with mainstream ideals as they may appear to be.

In his chapter, 'Your Future Employer-Yourself', in the Committee for Economic Development of Australia's report, Australia's Future Workforce, Ken Phillips (2015) cites the following statistic:

Globally, around 97 per cent of businesses are small (with fewer than five employees) and around 60 per cent of businesses are non-employing businesses of one. The people who run the dominant number of businesses are not command-and-control firms. They are more 'consumer-like' than anything else in the way they behave. This must turn on its head the prevailing acceptance by economists of how a market economy operates. To date, there's little evidence that economic policymakers see this, understand it or have even adapted any of their thinking in this direction. (190)

Further, Phillips (2015) states: 
Self-employment can be seen as a 'rising-star', not just because of increasing numbers of self-employed people. It's more because self-employed individuals are at the cutting-edge of cultural and attitudinal change in global workforces. The supremacy of the organisation is fading and being replaced with the authority of the individual. (180)

Key to what drives many of the individuals we interviewed for this study is a recognition that, as leading sociologist Zygmunt Bauman (2008) has stated:

\begin{abstract}
About half the goods crucial for human happiness have no market price and can't be purchased in shops. Whatever your cash and credit standing, you won't find in a shopping mall love and friendship, the pleasures of domesticity, the satisfaction that comes from caring for loved ones or helping a neighbor in distress, the self-esteem to be drawn from work well done, gratifying the 'workmanship instinct' common to us all, the appreciation, sympathy and respect of workmates and other people with whom one associates; you won't find there freedom from the threats of disregard, contempt, snubs and humiliation. Moreover, earning enough money to afford those goods that can only be had through the shops is a heavy tax on the time and energy available to obtain and enjoy non-commercial and non-marketable goods like the ones listed above. It may easily happen, and frequently does, that the losses exceed the gains and the capacity of increased income to generate happiness is overtaken by the unhappiness caused by a shrinking access to the goods which 'money can't buy'. (5)
\end{abstract}

We might quibble over the accuracy of the 'about half' figure, but the larger point about the desire to achieve happiness and work-life equilibrium clearly resonates across the making stories featured in this chapter and across this book (Fig. 2.3).

But before moving on, it is important to acknowledge that what we are often talking about here are people's dreams and aspirations, which are always more difficult to attain and sustain in reality—and across a lifetime. As is always essential in commenting upon this study, it is important also to acknowledge that the capacity to engage in creative self-employment is not equally accessible to all. For many of our participants, their making is made possible by a relatively middle-class economic buffer (be it a work payout, savings, owning a home, other employment or a supportive partner/family), but what is also evident, especially when factoring in the experiences of the emerging makers cohort, is the degree to which 


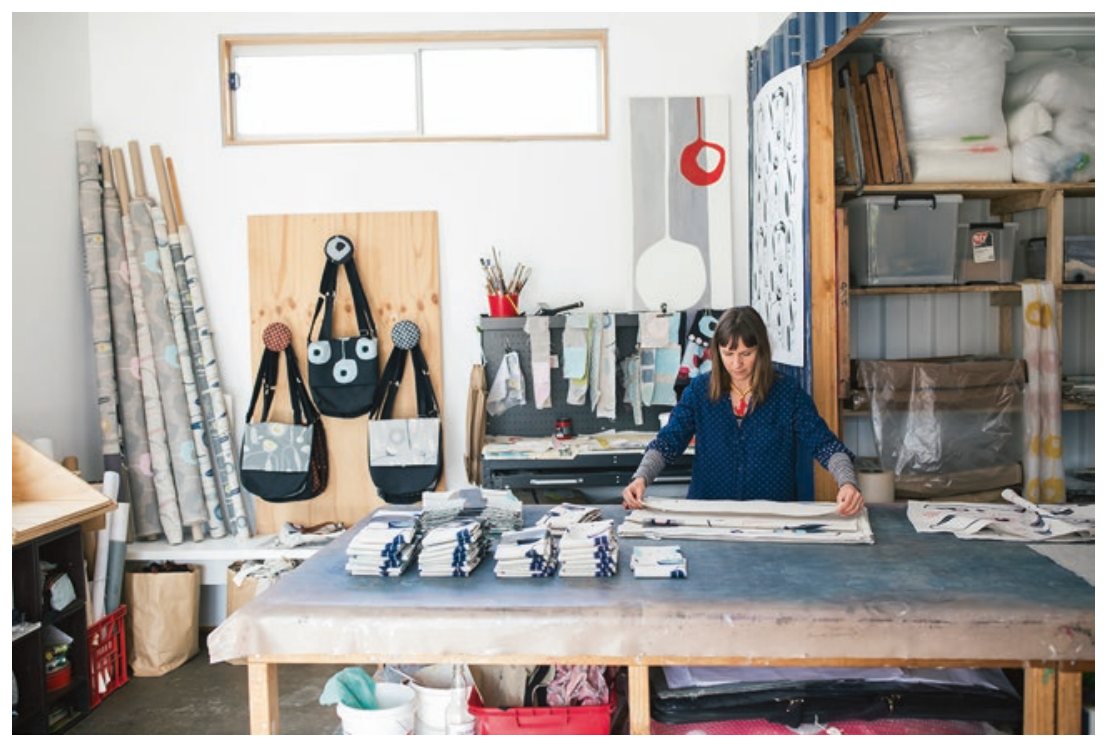

Fig. 2.3 Phillipa Julien, Till Designs (http://www.tilldesigns.com.au/), in her studio. (Photograph: Rosina Possingham Photography)

self-employment is an increasingly normalised social and economic expectation in an age of increasingly precarious contract-based, part-time, casual or otherwise insecure employment. In this context, creative selfemployment is a new normal, providing an identity beyond 'temporarily unemployed' and frequently masking low or negative incomes (Luckman and Andrew 2018). In such an environment, the desire to pursue meaningful work that one loves can be deployed as a strategy of the marketplace (the 'field of power') to facilitate individual and collective acceptance of the very kinds of work insecurities and exploitations from which people seek to escape. Alas, this compromise is something the larger economy (field of power) is increasingly finding useful to accommodate:

Additionally, even if the pay is low, then other forms of 'external' goodsuch as the prestige and social status of being recognised as an artist-may also provide the motivation to labour for low pay. [...] Yet while this might serve to secure kudos for the artist, it has also proved congenial to the capitalist who is able to more effectively exploit those who self-consciously dis- 
dain the need for earnings and who seek to obtain a 'cultural credit' through their wilful 'pecuniary neglect' (Ross 2000, 15). Andrew Ross (2000) has drawn attention to the impacts of what he has termed the 'cultural discount', the principle 'by which artists and other art workers accept nonmonetary rewards - the gratification of producing art-as compensation for their work, thereby discounting the cash price of their labour' (Ross, 2000, 6). (Banks 2017, 128)

Moreover, in this self-promotional age, McRobbie identifies within the creative sphere the rise of 'a (feminized) romantic ethic of production, rather than consumption' (McRobbie 2016, 108), which manifests in an "ethos of "passionate work", which envelops the identity of the cultural entrepreneur and which decorates his or her publicity material as a kind of statement of intent and declaration of suitability for participation in this sector' (McRobbie 2016, 74). With such self-presentation 'now a crucial part of the economic infrastructure', the affective labour of doing what you love is now a required and normalised part of many jobs across the Global North (Hearn 2017, 63). How higher education is increasingly being required not only to train students as experts in their practice areas but also to ensure graduates are ready to face this world prepared but not completely disillusioned is the focus of the next chapter.

\section{Notes}

1. The phrase 'tree change' or 'sea change' is used in Australia to refer to a residential shift from the city to the country; this usually comes with expectations of if not a bucolic existence, then at least a more relaxed lifestyle.

2. Perhaps the most overt current (at the time of writing) example of this is the National Australia Bank's 'This is the story of progress' screen advertisement as part of a larger 'More Than Money' campaign (National Australia Bank n.d.). The narrative focus of the ad is a voiced conversation between a father and daughter, as she enthusiastically outlines her plans while he expresses concern: 'Oh, you're not still on about that are you?', 'But your job. I mean you can't just throw that away' and finally 'Look, just promise me you won't do anything silly.' She assures him she would 'Never' do anything silly, as we see her walking towards the sunrise on her dreamed-of goat farm. The ad closes with the tag line, 'When you're ready to make it happen, so are we.'

3. Gabriella Coslovich's (2018) feature article, 'The would-be artisans who ditch day jobs to chase a dream', in The Age's Good Weekend Magazine (also simultaneously published in the same edition of the Sydney Morning Herald), explores the rise of interest in craft, handmaking, lost trades and the artisanal. It includes quotations from an interview with one of the authors of 
this book, reporting on the emerging findings from this study, and also features interviews with a number of makers of wooden furniture, ceramics, shoes and gin, who, often in conjunction with a partner or friend, have given up day jobs as police officers, journalists, architects and in public relations to pursue artisanal self-employment.

4. For further discussion of the pathways chosen by aspiring creatives as they seek to enter the creative workforce, see Taylor and Luckman (2020a).

5. In Luckman and Andrew (2018) we write about how engaging in creative self-employment or small business addresses a desire among especially educated, professional women previously employed outside the home to maintain an identity beyond 'mum' or 'homemaker'. In this way, crafting self-employment becomes a vehicle for also crafting a professional creative identity. For example, as a way to address these kinds of situations: '[My] working week, $[\ldots]$ so I'd probably, I roughly do two hours a night and then I have every second Friday off, so I'd work all that Friday because she's got to go to child care because you've got to pay for it anyway, so that gives me a good opportunity. So every fortnight we could say, I guess, so that would be an eight hour day on that Friday and then two hours every night, plus in the weekends. [...] I thought [working from home while the children are young] would be really easy, I really did, I thought oh she's asleep, and it's true, I do stuff and she's a good sleeper [...] but it's, yeah it is a hard challenge because just personally it's, there's a lot of pressure and then you've got that mother guilt thing, and then you've got "oh well", and I felt a bit guilty because [my partner] works so hard and I do have some guilt, [I'm] a dental nurse as a trade so I can, so it's taken me a long time to kind of come to terms with yes well I really should contribute. And it's weird now when people say "What do you do?", "I'm a stay at home mum", and people would look at you like you're a foreigner or weirdo, something, I don't know what, "Oh you don't go to work?" "No"” (Female, yarn worker, emerging maker, September 2015).

\section{ReFERENCES}

Banks, M. (2007). The Politics of Cultural Work. Basingstoke: Palgrave.

Banks, M. (2017). Creative justice: Cultural industries, work and inequality. London and New York: Rowman \& Littlefield International.

Bauman, Z. (2008). The art of life. Cambridge and Malden, MA: Polity.

BOP Consulting. (2012). Craft in an age of change (Commissioned by Crafts Council, Creative Scotland, Arts Council of Wales, and Craft Northern Island). London: BOP Consulting. Retrieved from http://www.craftscouncil.org.uk/ content/files/Craft_in_an_Age_of_Change.pdf. 
Bourdieu, P. (1993). The field of cultural production: Essays on art and literature. Columbia: Columbia University Press and Polity Press.

Bridgstock, R., \& Cunningham, S. (2016). Creative labour and graduate outcomes: Implications for higher education and cultural policy. International Journal of Cultural Policy, 22(1), 10-26.

Brook, S. (2016a). The exemplary economy: A Hunterian reading of the creative industries as educative project. International Journal of Cultural Policy, $22,27-40$.

Brook, S. (2016b). The creative turn in Australian higher education. In R. Comunian \& A. Gilmore (Eds.), Higher education and the creative economy (pp. 242-260). London: Routledge.

Coslovich, G. (2018). The would-be artisans who ditch day jobs to chase a dream. The Age, May 12. Retrieved February 6, 2020, fromhttps://www.theage.com. au/business/workplace/the-would-be-artisans-who-ditch-day-jobs-to-chasea-dream-20180509-p4ze5e.html.

Cunningham, S., \& Bridgstock, R. (2012). Say goodbye to the fries: Graduate careers in media, cultural and communication studies. MIA Media International Australia, 145, 6-17.

Dudley, K. M. (2014). Guitar makers: The endurance of artisanal values in North America. Chicago and London: The University of Chicago Press.

Gibson-Graham, J. K. (2006). A post-capitalist politics. Minneapolis, MN: University of Minnesota Press.

Gill, R. (2014). Unspeakable inequalities: Post feminism, entrepreneurial subjectivity, and the repudiation of sexism among cultural workers. Social Politics: International Studies in Gender, State and Society, 21(4), 509-528.

Hearn, A. (2017). Verified: Self-presentation, identity management, and selfhood in the age of big data. Popular Communication, 15, 62-77.

Hesmondhalgh, D., \& Baker, S. (2011). Creative labour: Media work in three cultural industries. London and New York: Routledge.

Johnson, R. (1993). Editor's introduction. In P. Bourdieu (Ed.), The field of cultural production: Essays on art and literature. Columbia: Columbia University Press and Polity Press (Blackwell Publishers).

Knott, S. (2015a). Labour of love. Crafts (no. 255, July/August, 2015), p. 51.

Knott, S. (2015b). Amateur craft: History and theory. London and New York: Bloomsbury.

Luckman, S. (2018). Craft entrepreneurialism and sustainable scale: The persistence and evolution of creative challenges to capitalist growth. Cultural Trends, $27(5), 313-326$.

Luckman, S., \& Andrew, J. (2018). Online selling and the growth of home-based craft microenterprise: The 'new normal' of women's self-(under)employment. In S. Taylor \& S. Luckman (Eds.), The new normal of working lives: Critical 
studies in contemporary work and employment (pp. 19-39). Cham: Palgrave Macmillan.

McRobbie, A. (2016). Be creative: Making a living in the new culture industries. Cambridge and Malden: Polity.

National Australia Bank.(n.d.). This is the story of progress (advertisement). Retrieved November 14, from https://www.nab.com.au/about-us/morethan-money/progress.

O'Connor, J. (2016). After the creative industries: Why we need a cultural economy. Sydney: Currency House.

Ocejo, R. E. (2017). Masters of craft: Old jobs in the new urban economy. Princeton and Oxford: Princeton University Press.

Patrick, A. (2019). Australia is rich, dumb and getting dumber. Australian Financial Review, October 8, 2019.

Phillips, K. (2015). Your future employer-Yourself. In Committee for Economic Development of Australia (CEDA), Australia's future workforce (pp. 179-191). Melbourne: CEDA.

Ross, A. (2000). The Mental Labour Problem. Social Text 18(2), 1-31.

Ross, A. (2007). Nice work if you can get it: The mercurial career of creative industries policy. In G. Geert \& N. Rossiter (Eds.), My creativity reader: A critique of creative industries (pp. 19-41). Amsterdam: Institute of Network Cultures.

Taylor, S., \& Littleton, K. (2016). Contemporary identities of creativity and creative work. London and New York: Routledge.

Taylor, S., \& Luckman, S. (Eds.). (2018). The new normal of working lives: Critical studies in contemporary work and employment. Cham: Palgrave Macmillan.

Taylor, S., \& Luckman, S. (2020a). Creative aspiration and the betrayal of promise? The experience of new creative workers. In S. Taylor \& S. Luckman (Eds.), Pathways into creative working lives. Cham: Palgrave Macmillan.

Taylor, S., \& Luckman, S. (2020b). New pathways into creative work? In S. Taylor \& S. Luckman (Eds.), Pathways into creative working lives. Cham: Palgrave Macmillan.

Wilson, K. (2017). Tinkering: Australians reinvent DIY culture. Clayton: Monash University Publishing. 
Open Access This chapter is licensed under the terms of the Creative Commons Attribution 4.0 International License (http://creativecommons.org/licenses/ by $/ 4.0 /)$, which permits use, sharing, adaptation, distribution and reproduction in any medium or format, as long as you give appropriate credit to the original author(s) and the source, provide a link to the Creative Commons licence and indicate if changes were made.

The images or other third party material in this chapter are included in the chapter's Creative Commons licence, unless indicated otherwise in a credit line to the material. If material is not included in the chapter's Creative Commons licence and your intended use is not permitted by statutory regulation or exceeds the permitted use, you will need to obtain permission directly from the copyright holder. 